\title{
ÉTICA E MORAL EM SANTO AGOSTINHO: UMA ANÁLISE DA DEONTOLOGIA AGOSTINIANA COM FULCRO EM TRÊS CÉLEBRES OBRAS DO AUTOR - CONFISSÕES, LIVRE-ARBÍTRIO E CIDADE DE DEUS / ETHICS AND MORALITY IN SAINT AUGUSTINE: AN ANALYSIS OF AUGUSTINIAN DEONTOLOGY WITH FULCRUM IN THREE CELEBRATED WORKS OF THIS AUTHOR - CONFESSIONS, FREE WILL AND CITY OF GOD
}

\author{
Caryne AbbadeCapitanio \\ Bacharelanda em Direito pela Universidade Federal do Estado do Rio de Janeiro - UNIRIO. Estagiária da \\ Empresa Souza Cruz.
}

\section{Larissa Camargo Costa}

Bacharelanda em Direito pela Universidade Federal do Estado do Rio de Janeiro - UNIRIO. Estagiária da FIRJAN - Federação das Indústrias do Estado do Rio de Janeiro

\section{Rafael da Silva Alvim}

Bacharelando em Direito pela Universidade Federal do Estado do Rio de Janeiro - UNIRIO. Estagiário da Procuradoria da República do Estado do Rio de Janeiro.

\section{Edna Raquel Hogemann}

Doutora em Direito - Universidade Gama Filho; especialista em Bioética pela Cátedra em Bioética Unesco (Caribe); professora permanente do Programa de Pós-Graduação em Direito (Mestrado/Doutorado) - Universidade Estácio de Sá; professora do curso de Direito - Universidade Federal do Estado do Rio de Janeiro; pesquisadora da Fundação de Amparo à Pesquisa do Estado do Rio de Janeiro; membro da Comissão de Direitos Humanos da OAB (Duque de Caxias); membro associado da SBPC.

\section{Resumo}

O presente artigo visa abordar os principais aspectos da Ética da Deontologia em Santo Agostinho por meio de uma abordagem histórica do contexto em que viveu o autor e através de uma análise de três das suas principais obras: "Livre-Arbítrio", "Confissões" e "Cidade de Deus". O estudo busca destrinchar o pensamento Agostiniano e demonstrar os argumento sob os quais inaugurou, o Bispo de Hipona, um novo modelo moral, ético e filosófico de viés eminentemente teológico.

Palavras-chave: Deus, ética, deontologia, cristianismo.

\begin{abstract}
The present article aims to expose the main aspects of the Deontological Ethics in Santo Agostinho through a historical analysis of the context in which lived the author and through an analysis of his first three books: "Freewill", "Confessions" and "City of God". This study seeks to focus Agostinian thought and demonstrate the arguments under which started, the Bishop of Hipona, a new moral, ethic and philosophical model, in a theological perspective.
\end{abstract}


Key-words: God, ethics, deontology, christianity,

1 - Introdução; 2 - Aspectos Preliminares; 3 - Santo Agostinho, a negação do maniqueísmo e o livrearbítrio; 4 - Moral Cristã; 5-Autobiografia - "As Confissões de Santo Agostinho"; 6- Ética Agostiniana em "A Cidade de Deus"; 7- A ética da deontologia em Santo Agostinho.

\section{Introducão}

O conceito de ética e moral não é algo estático que sobreviveu às barreiras do tempo e às mutações sociais. Pelo contrário. O entendimento da ética e da moral transformouse ao longo da evolução do homem.

Através de um estudo preliminar e superficial dessas transformações, tem-se que no período da Grécia Antiga, compreendendo o lapso temporal do século V ao século IV a. C., o pensamento Sofista, Sócrates, Platão e Aristóteles como destaque sob as teorias éticas fundamentais. Já no período Helenístico e Romano, a relação entre a natureza, os cosmos e o homem ganha destaque nas teorias, dando-se destaque aos pensamentos Epicuristas, Cínicos, Estóicos e Cépticos.

Passando, agora, ao período da Idade Média, estendendo-se entre o século IV ao século $\mathrm{XV}$, no qual a moral cristã ganha predomínio absoluto, ganham destaque as teorias éticas fundamentais de Santo Agostinho e São Tomás de Aquino. Após, no período entre o século XVI e XVII, conhecido como Idade Moderna, a sociedade é marcada por mudanças trazidas pelo Renascimento, pelas descobertas geográficas e pela Cisão da Igreja, dando-se destaque, assim, a filósofos como Descartes, John Locke e David Hume.

Por fim, na Idade Contemporânea, inúmeras teorias filosóficas e morais ganham força, ganhando evidência os nomes de Kant, Sartre, Habermas, Hans Jonas, dentre outros que, infelizmente, o curto âmbito deste artigo impede citar e dar maior aprofundamento.

Desse modo, o único caráter que se manteve inerte ao longo do período histórico de evolução do homem foi a finalidade que "ethos", do Grego, e "moralis", do Latim, exerce sobre a conduta humana, qual seja, guia-la de forma a criar as bases do caráter e das virtudes a fim construir a vida em sociedade.

\section{Aspectos preliminares}


Santo Agostinho vive no fim do período designado como filosofia antiga (dominado pelas correntes helenísticas, céticas, estóicas e neoplatônicas). O filósofo recebe inegável influência do neoplatonismo, chegando a reconhecer (nas suas Confissões) que os livros de orientação neoplatônica desempenharam papel central no seu desenvolvimento enquanto filósofo e religioso, inclusive em sua conversão ao cristianismo, em 386. Também influenciaram em grande medida o pensamento do filósofo (no que tange à sua conversão) as Epístolas de Paulo de Tarso.

Outrossim, antes de decidir-se pela religião cristã, Agostinho filiava-se à corrente de pensamento maniqueísta (fundada pelo profeta Maniqueu, crucificado na Pérsia em 277). Neste sentido, transferindo-se para Cartago (atual Tunísia) em 372 d.C., Agostinho descobre o pensamento de Cícero, de quem tornar-se-ia discípulo, passando a conhecer as correntes do neoplatonismo, do estoicismo e do epicurismo.

Ainda em Cartago, Agostinho entrega-se à leitura das Sagradas Escrituras (em 374 d.C., o Edito de Teodósio havia tornado o Cristianismo a religião oficial do Império Romano do Oriente). Todavia, considera a Bíblia Sagrada “indigna da comparação com a elegância ciceroniana". A leitura da Bíblia, contudo, incute em Agostinho uma das questões que mais o intrigam durante sua vida: “Qual é a origem do mal?”.

$\mathrm{Na}$ busca de uma resposta para este questionamento, Agostinho busca o pensamento Maniqueísta $^{2}$ (que se baseia em uma teoria dualista, segundo a qual existem um princípio celeste de trevas e outro de luz). As felicidades e as tristezas da vida advêm de uma batalha incessante entre o Reino da Luz e o Reino das Trevas. O Maniqueísmo, portanto, era a doutrina segundo a qual a força cósmica do mal é igual em poder à força cósmica do bem - embora possamos nos aliar à força do bem, ao princípio da Luz, podemos esperar que a força do mal continue a contrabalançar a bondade no mundo.

Aos vinte e dois anos de idade, Santo Agostinho começa a lecionar retórica em Cartago. Tendo o desejo de ver solucionados diversos questionamentos de ordem

\footnotetext{
1 “Agostinho foi criado como um cristão por sua mãe na África do Norte, mas, na juventude, quando estudava em Cartago, ficou insatisfeito com a aparente simploriedade das escrituras cristãs." LAW, Stephen. Guia ilustrado Zahar: filosofia. Tradução: Maria Luiza X. de A. Borges; revisão técnica: Danilo Marcondes. Rio de Janeiro: Jorge Zahar Ed., 2008, p. 256.

2 “Agostinho abandonou a fé cristã inicial sobretudo por não poder compreender a idéia de um criador imaterial do universo material, e por sua incapacidade de lidar com os problemas do mal e do sofrimento. Esta última dificuldade surge da fé cristã de que seu Deus-criador é onisciente, misericordioso e onipotente. Um ser assim teria conhecimento do mal em sua criação e seria tanto propenso a quanto capaz de eliminá-lo. Talvez não surpreenda, portanto, que o maniqueísmo tenha parecido de início mais satisfatório a Agostinho, pois caracteriza o universo em termos de luta entre o bem e o mal." Op. Cit., p. 257.
} 
filosófica acerca do pensamento maniqueísta, procura esclarecimentos com Fausto (bispo maniqueísta). Sua decepção é flagrante, passando a desacreditar na capacidade da teoria maniqueísta de responder satisfatoriamente às suas indagações. Acerca disto, o filósofo assevera em suas Confissões:

"Quando lhe expus algumas das dúvidas que me perturbavam, descobri rapidamente que das artes liberais ele conhecia apenas a gramática e a literatura, e seu conhecimento nada tinha de extraordinário, [apenas] convencional. Tinha lido algumas orações de Cícero, pouquíssimos tratados de Sêneca, algumas poesias e os poucos livros da seita, escritos em um latim de bom estilo."

Em 385 d.C., com 31 anos, Agostinho passa a lecionar em Milão. Neste período é que o filósofo ira tomar lições de Santo Ambrósio, bispo da cidade. Foi este quem o conduziu a romper suas ligações ideológicas com o Maniqueísmo ${ }^{3}$. Acerca de sua ruptura com tal doutrina, Agostinho assevera:

\begin{abstract}
“Apliquei, então, energicamente as minhas faculdades críticas para ver se de alguma forma poderia, com argumentos decisivos, provar que os maniqueístas estavam errados. Se a minha inteligência pudesse conceber uma substância espiritual, imediatamente se apegariam e seriam extirpadas de minha alma todas aquelas invenções. Mas não podia. Entretanto, quanto mais meditava, avaliando e comparando as teorias acerca do mundo físico e de toda a ordem natural acessível aos sentidos do corpo, mais e mais me convenci de que numerosos filósofos sustentavam opiniões muito mais prováveis que as deles."
\end{abstract}

Tendo, de um lado, sido frustrado pela perspectiva filosófica maniqueísta e, de outro, sido conduzido ao pensamento neoplatônico ${ }^{4}$ e cristão por Santo Ambrósio, Agostinho foi abandonando os pressupostos do pensamento maniqueísta. Todavia, voltava a indagar acerca da problemática bem $x$ mal, já que não conseguia introjetar a concepção maniqueísta sobre a temática. Neste sentido, mais tarde, em suas Confissões, Santo Agostinho discorreria da seguinte forma acerca da filosofia maniqueísta:

\footnotetext{
3 “Agostinho seguiu inicialmente a seita maniqueísta, que proclamava a existência de uma luta constante entre o princípio do bem e do mal, porém, ao estabelecer contato com Santo Ambrósio, em Milão, e com os escritos de Plotino, abandonou o materialismo e converteu-se à religião cristã, ordenando-se sacerdote e, quatro anos após, sagrando-se Bispo de Hipona, antiga cidade da Numídia, onde veio a falecer." NADER, Paulo. Filosofia do direito. Rio de Janeiro: Forense, 2009, p. 120.

4 "Embora não seja considerado um aristotélico, mas um platônico, Agostinho reconhece que as considerações de Aristóteles sobre a natureza dos atos voluntários eram contundentes, entretanto faltavalhe afirmar a liberdade da vontade. Diferente de Aristóteles, que estabelecia um vínculo entre vontade e ação, Agostinho afirma que a liberdade é fundamentalmente uma manifestação da vontade individual, que coloca o homem em contato com suas faculdades interiores (...). Nisto consiste a liberdade individual do homem: ser livre em relação a si mesmo." COSTA, Marco Roberto Nunes. "O amor: princípio da moral interior em Santo Agostinho”. In: Revista Perspectiva Filosófica, p. 123. Disponível em http://www.ufpe.br/ppgfilosofia/images/pdf/pf09_artigo80001.pdf. Acesso em 24de março 2013.
} 
"Não conhecem o caminho pelo qual, deixando o orgulho, iriam até o Salvador e por ele, subiriam novamente a ele; ignoram este caminho e se consideram tão elevados e cintilantes quanto os astros; tombaram por terra, com o coração coberto pelas trevas da ignorância. Dizem muitas verdades sobre as criaturas, e não buscam devotamente a verdade, artífice da criação; assim, não a encontram, ou, se a encontram, embora conhecendo a Deus, não lhe prestam honra como a Deus, são teus; e se empenham, cegos e perversos, em atribuir-te o que propriamente pertence a eles: transferem suas falsidades a ti, que é a Verdade, e assim 'trocam a glória do Deus incorruptível por imagens do homem corruptível, de aves, quadrúpedes e répteis, trocam a verdade pela mentira, e adoram e servem a criatura em lugar do Criador (...)'."

Nesta seara, cabe traçar uma breve comparação das dicotomias ínsitas ao dualismo da filosofia cristã agostiniana ${ }^{5}$, em parte assemelhada ao maniqueísmo: ao corpo, contrapõe-se a alma; ao pecado, traduzido por uma vida levada de acordo com os prazeres materiais, opõe-se a virtude; a concupiscência (definido por Santo Agostinho como o desejo pelos bens materiais) encontra contraponto na caridade; a bioscarnalis (vida em busca das paixões carnais) é a antítese da biostheoretikos (vida contemplativa, em busca da verdade revelada por Deus ${ }^{6}$ ).

\section{Santo Agostinho, a negacão do maniqueísmo e o livre-arbítrio}

Aos poucos, Agostinho desenvolve noções que suplantam o ideário maniqueísta (de que a conduta má seria fruto da batalha entre Bem e Mal). Para isso, concorreram as leituras dos neoplatônicos Plotino (205 d.C. - 270 d.C.) e Porfírio (232 d.C. - 304 d.C.). Conforme vimos, Agostinho preocupa-se em encontrar uma resposta satisfatória para suas indagações acerca da origem do bem e do mal, bem como da liberdade humana questões estas que, segundo o filósofo, o maniqueísmo não foi capaz de responder satisfatoriamente.

Das lições de Santo Ambrósio e da leitura de Plotino, (que mais tarde também o conduziriam ao Cristianismo), filósofo discípulo de Platão, Santo Agostinho passa a

\footnotetext{
5 "Em oposição à dualidade maniquéia, Agostinho instaura o Bem como único princípio existente - Deus - e o mal como sua simples negação. Em outras palavras, o mal, na concepção agostiniana, não tem existência ontológica, não é, portanto, um princípio de força antagonicamente equiparada ao bem, como supunham os maniqueus." COUTINHO, Gracielle Nascimento. "O Livre-arbítrio e o Problema do Mal em Santo Agostinho". In: Revista Argumentos, ano 2, $\mathrm{n}^{\circ} 3-2010$, p. 126. Disponível em http://www.filosofia.ufc.br/argumentos/pdfs/edicao_3/l6.pdf. Acesso em 24de março 2013.

6 "Só Deus é inteiramente real; o mundo criado é menos real por estar distante dele. Ao mesmo tempo, Deus ilumina objetos de contemplação intelectual. Assim, enquanto os sentidos são uma fonte inconfiável de conhecimento, a compreensão genuína começa com a contemplação da própria mente e eleva-se gradualmente rumo à contemplação de Deus.” Op. Cit., p. 257.
} 
adotar entendimento segundo o qual "o livre arbítrio da vontade é a razão pela qual praticamos o mal e sofremos a justa punição [imposta por Deus]". Contudo, persistia a indagação: como o ser humano, fruto da criação, poderia apresentar tendência a praticar o mal, sendo ele resultado da obra de Deus, que é a Bondade Suprema? Em sua obra "O Livre-Arbítrio" (De libero arbitrio) (388-395), indaga:

\begin{abstract}
"Quem me criou? Não foi o meu Deus, que é não só bom, mas a suprema Bondade? Donde me veio, entoa, o impulso para querer o mal e não querer o bem? Seria para fornecer uma razão que justifique o fato de eu sofrer uma punição?... Se foi o diabo o responsável, donde foi que ele veio? E se, por uma decisão de sua vontade perversa, se transformou de anjo bom que era em diabo, qual é a origem dessa vontade má que dele fez um diabo, quando um anjo é inteiramente obra de um Criador que é pura bondade?"
\end{abstract}

A concepção do ser humano em Santo Agostinho adota o homem como criatura de Deus ${ }^{7}$, corrompido naturalmente pelo pecado de Adão e Eva, e cujos pecados apenas encontrariam remissão na Graça Divina. Tendo sido feito à imagem e semelhança de Deus (Gn, 1:26), o homem é dotado de uma alma que se reparte em três faculdades (dons) distintas: a memória, enquanto manutenção das imagens assimiladas pelo homem, corresponderia a Deus (da qual sua criatura nunca deverá se esquecer); a inteligência como análogo ao verbo, ou à $\mathrm{raza}^{8} \mathrm{o}^{8}$ (Filho): a vontade seria a expressão do amor de Deus por suas criaturas (Espírito Santo). Destas qualidades da alma, Agostinho atribui maior importância à vontade, posto que através dela quis Deus dar às suas criaturas a liberdade. Assim, a partir da vontade, por ser essencialmente livre, pode o homem afastar-se ou aproximar-se de seu Criador.

A obra supracitada é escrita por Agostinho em resposta à formulação determinista dos maniqueístas, que concebem o mal como metafísico e ontológico - concebendo o homem mau como fadado à prática do mal e o homem bom como destinado à prática do bem. Na obra, Santo Agostinho busca discutir três questões fundamentais:

I) Na primeira parte (Livro I), perquire a essência do mal - em síntese, percebe que o homem comete o mal quando submete a sua vontade às suas paixões, ou

\footnotetext{
7 "Na doutrina de Santo Agostinho, Deus seria o princípio de todas as coisas. O Direito Positivo se fundamentaria, em último grau, na lei eterna, que é a lei de Deus. A exemplo de Ulpiano e Cícero, concebeu a justiça como virtude: 'justitia et virtus este quae sua cuique distribuit'.” Op. Cit., p. 120.

8 "Mas superior à razão está a Verdade absoluta. A Verdade que, para o Bispo de Hipona, não pode ser buscada no mundo externo, mas no interior do próprio homem. Apesar dessa busca ser feita na interioridade humana, a verdade não pode ser buscada apenas como uma verdade individual, subjetiva. A Verdade é algo superior ao próprio homem, pois está acima da razão humana.” BELLEI, Ricardo J.; BUZINARO, Délcio Marques. O livre-arbítrio e o mal em Santo Agostinho (p. 90). Disponível em http://www.revistamirabilia.com/nova/images/numeros/2010_11/04.pdf. Acesso em: 25de março de 2013.
} 
quando deixa de lado as promessas divinas para satisfazer paixões da matéria. A resposta a esta investigação já se revela de maneira enfática no título do Livro I (O pecado provém do livre-arbítrio) e na segunda parte do mesmo livro ( $A$ causa do pecado - o abuso da vontade livre)/

II) Na segunda parte (Livro II), Santo Agostinho prova a existência de Deus, criador e fonte de todo o bem;

III) Na terceira e última parte (Livro III), Agostinho trata da Providência Divina em relação aos seres dotados de liberdade.

Na obra $O$ Livre Arbitrio, consistente em diálogos entre o filósofo e Evódio (amigo de Santo Agostinho), formula uma explicação para a existência do mal que se mantém até a contemporaneidade.

Se Deus é o criador de tudo que há, e se Deus é a mais pura expressão do bem, de onde vem o mal? - Para responder a este questionamento, o filósofo recorre ao neoplatonismo em Plotino, de onde dirá que o mal não é por si só, mas que depende da ausência ou da deficiência do bem para existir.

O pecado é inserido na obra de Santo Agostinho como a definição do mal moral ${ }^{9}$ (ao lado do mal a nível metafísico-ontológico e físico ${ }^{10}$ ): o pecado depende da mávontade do homem ${ }^{11}$. Dada a natureza da criação humana, a vontade do homem deveria sempre tender para o bem. Como, contudo, há, no plano da criação, diversos bens

\footnotetext{
9 “O homem sempre será imputado de sua responsabilidade quando agir mal, ou seja, quando não agir em conformidade com a ordem das coisas criadas por Deus. Agostinho sustenta que há no homem uma vontade que é livre, e que do ponto de vista moral, deve ser utilizada para fazer o bem. Se isso não acontecer, ele será o total responsável. Dessa maneira, a responsabilidade pela prática do mal moral (pecado) é exclusiva do homem." Op. Cit., p. 85.

10 "O mal físico, como, por exemplo, as doenças, os sofrimentos e a morte, tem para quem reflete na fé, um significado muito preciso: eles são as conseqüências do pecado original. São, portanto, consequiências do mal moral. A corruptibilidade do corpo não é causa, mas sim pena do primeiro pecado. (...). Portanto, o mal físico não constitui uma nova modalidade de mal, mas, sim, apenas um desdobramento do mal moral, o que deve realmente ser analisado." Idem, p. 87.

11 “(...) segundo o filósofo cristão santo Agostinho, também o mal natural resulta do mal moral - e de um evento bíblico em particular. A opção de Adão e Eva por desobedecer a Deus levou à "queda", uma mudança metafísica que alterou a natureza e os homens para sempre. As consequiências da queda são a inimizade entre os homens e os animais, as dores do parto e as agruras que devemos suportar para sobreviver (Gênesis 3:15-19). Todo o mal, seja natural ou moral, foi assim causado pelo livre-arbítrio humano." Op. Cit., p. 155.
} 
criados e finitos, a vontade humana pode vir a tender a eles ${ }^{12}$. Assim, o homem peca ao preferir buscar a criatura ao Criador, subvertendo ${ }^{13}$ a divina ordem hierárquica.

Assim, o livre arbítrio ${ }^{14}$ é

"um grande bem que a criatura recebeu de Deus, seu criador. O mal nasce do mal uso deste grande bem, pelo qual a criatura, através de suas paixões, pode vir a se afastar do Criador."

\section{Moral Cristã}

A moral, vocábulo de origem no latim, está relacionada diretamente aos costumes, podendo ser definida, latu sensu, como o conjunto de normas aplicadas no cotidiano e usadas reiteradamente por cada cidadão, regulando, assim, o comportamento do homem em sociedade. Essas regras são adquiridas através da educação, tradição e vida em comunidade e irão nortear as ações e julgamentos dos homens sobre o que moral ou imoral, certo ou errado e bom ou mau.

Já a moral oriunda do cristianismo, foca-se em núcleos como amor, paz de espírito, harmonia, caridade e humildade. Através dela, Deus é visto como sinônimo do bem, justiça e verdade.

Assim, a moral cristã estabelece o pensamento de que o homem deverá encontrar suas virtudes essenciais, para assim encontra-se com Deus, pois somente através Dele é possível alcançar a felicidade plena e encontrar soluções às aflições terrenas do ser humano.

Neste contexto, o cristianismo defenderá que o caminho das condutas e morais focadas na santidade e no perdão é o melhor a ser seguido, e a leitura da Bíblia mostrará os critérios metodológicos aptos a facilitar o acesso a esse caminho da reflexão moral.

\subsection{A moral para Santo Agostinho}

\footnotetext{
${ }^{12}$ Em sua obra Contra fortunatummanichaeum, Acta seu disputatio (Cap. 20), Santo Agostinho assevera expressamente que "Deus não é a fonte dos males (...) eles existem devido ao pecado voluntário da alma, à qual Deus deu livre escolha." Op. Cit., p. 257.

13 "Quando o homem faz o caminho inverso preferindo os bens inferiores aos superiores perverte a ordem estabelecida por Deus no universo: eis o mal ou o pecado. É desta forma que se deve compreender o pecado original; porque má não era a árvore do fruto proibido, mas a desobediência do homem ao Criador, superior a todas as coisas." Op. Cit., p. 128.

14 “Apesar de o livre-arbítrio ser um bem, Agostinho reconhece que ele é um bem médio, pois, por ele, podemos tanto fazer o bem quanto o mal. Para isso ele faz uma hierarquia dos bens no homem. No mais elevado grau estão as virtudes, pelas quais o homem não pode pecar, pois elas ninguém usa mal. Depois vêm os bens médios, que são bens que podem tender tanto para o bem quanto para o mal." Op. Cit., p. 96.
} 
A teoria moral de Santo Agostinho apresenta a moral cristã aos seus adeptos. Para ele, o objetivo da moral e da vida é encontrar a felicidade dos seres humanos, e esta somente poderá ser alcançada através do encontro com Deus, pois somente amando a Deus é possível ser verdadeiramente feliz.

A moral agostiniana afirma que só viverá de forma moralmente perfeita aquele que procurar atingir o Bem Supremo. Assim, toma como base a experiência do Império Romano, pois os romanos foram enaltecidos e glorificados através da prática de virtudes como o amor á pátria, o apreço pela honra e o desejo e liberdade, e com isso chegaram ao reconhecimento de Deus. Contudo, cometeram crasso erro moral ao sobreporem os bens mutáveis pelos imutáveis.

Para o Santo Teólogo, a virtude por excelência é conhecer e imitar a Deus, sendo ele a única fonte de felicidade. Desse modo, erraram os romanos ao praticarem virtudes com o intuito imediato de obter grandeza e poder, ao invés de darem expressão ao objetivo íntimo e profundo que é conhecer a Deus e gozar do Bem Superior.

Logo, para o pensamento moral do Pastor de Hipona, o caminho das virtudes que o homem deve seguir é o da felicidade, entendo a virtude como o amor perfeito de Deus, pois de nada importam os prestígios da glória humana.

A ética agostiniana também está diretamente ligada ao que já foi exposto, pois para ele o homem se revela por aquilo que ama. Assim, a "ethos" é aquela que ajuda o ser humano a viver de acordo com o amor em Deus, pois Ele é a finalidade de toda a criação. Por isso que a ética do Santo Agostinho girará em torno da ideia de que a felicidade do homem consiste em unir-se ao seu Criador, pois somente amando verdadeiramente a Deus é possível amar a si mesmo e ao próximo, tendo em vista que só desta maneira é verdadeiramente livre.

\section{Autobiografia - "As Confissões de Santo Agostinho"}

O Santo Teólogo possui inúmeros textos publicados, pela leitura dos quais é possível conhecer a grandeza do seu pensamento no que tange á ética e moral com relação estrita a paz de espírito que encontrou no amor em Deus.

Um dos livros mais conhecidos de Santo Agostinho é o "Confissões". Esta obraprima é considerada a primeira autobiografia, e sua riqueza extraordinária é extremamente importante tanto para a teologia quanto para a literatura em geral. 
Suas confissões foram escritas entre os anos de 397-398 d. C. e descrevem a trajetória de sua vida desde sua concepção até o momento que as escreveu, por volta dos 50 anos, demonstrando sua relação com Deus, e inclusive, diga-se, com inocência, esta intencional ou não, contando seus pecados até sua total entrega interior a fé. Assim, a auto revelação e consciência psicológica continuam a impressionar séculos e séculos após sua confissão. A obra é dividida em duas partes e composta de 13 (treze) livros.

A primeira impressão que a magnífica obra traz é o papel traçado pelo Bispo de Hipona em enaltecer a moral cristã, como bem salientado no texto do mineiro Adriano José Gonçalves ${ }^{15}$ :

Advogar uma causa sempre é um desafio. Porém, advogar uma causa que ainda está se formando, que ainda não tem um corpo definido, este sim é um desafio "titânico", pois exige muito mais daquele que assume esta causa.

E o desafio "titânico" assumido por Santo Agostinho foi a defesa do cristianismo na tentativa de solidificá-lo no período que a fé cristã estava nascendo em meio a outros credos e cultos, pois defender uma "fé estabelecida ou já definida não é o mesmo que defender uma fé nascente, ainda tomando sua forma".

Em síntese, tem-se a obra de um sacerdote convertido já na vida adulta, por volta dos 32 anos, pela qual narra sua vida anterior ao celibato, com visão rigorosamente condenatória, do Livro Primeiro ao Nono. Ao cabo, nos livros restantes, resume, em termos filosóficos, o que seria o encontro com Deus, sendo em sua essência um grande louvor à grandeza de Deus. Através do livro é possível entender como este homem foi $\underline{\text { santo e como este santo foi homem. }}$

\section{1 "Primeira Parte: Desatinos de outrora, conversão e batismo".}

Neste capítulo, buscar-se-á fazer uma superficial análise da vida e do pensamento de Santo Agostinho em cada um dos 9 livros que compõem a primeira parte da obra "Confissões".

Apenas para ilustrar, cumpre explicar que toda a trajetória do livro demonstra que o Bispo de Hipona dirige seus questionamentos a Deus, contudo percebe-se que as respostas vêm do seu interior, ao conhecer a si mesmo para conhecer a Deus, pois sem

\footnotetext{
${ }^{15}$ Disponível em: http://www.catequisar.com.br/texto/colunas/adriano/10.htm (Introdução às Confissões de Santo Agostinho Capítulo 2 por Adriano José Gonçalves). Acesso em: 26 de março de 2013.
} 


\section{Quaestio Iuris}

vol.05, $\mathrm{n}^{\circ} 01$. ISSN 1516-0351

Ele não poderá continuar a existir "já que não existiria se em mim não habitásseis" (Conf. I, 2, 2).

O Livro I, denominado “A Infância”, dedica-se a relatar a infância e período da vida compreendido entre a infância e a adolescência de Santo Agostinho, ressaltando de maneira exaustiva a sua educação, tanto nos hábitos da vida, como na educação escolar.

Já no Livro II, apelidado "Os Pecados da Adolescência", Santo Agostinho descreve os pecados da adolescência, demonstrando a confusão de sentimentos que experimentou aos 16 anos. Escreveu sobre as desordens da juventude, mostrando o mal que o pecado traz na vida humana, e quão amável é a misericórdia divina. O adolescente reconhece para si o sentimento de liberdade enxergando nos prazeres ilícitos sua felicidade, mas com o tempo reconhece que a felicidade está no caminho de Deus.

Seguindo ordem cronológica, o Livro III, chamado "Os Estudos", traz as confissões de um homem preso as paixões terrenas, que não consegue enxergar a pureza do amor e a verdadeira felicidade residida em Deus. Neste período, Agostinho tem o primeiro contato com as Sagradas Escrituras, contudo sua paixão, á época, pela materialidade o impede de um entendimento mais profundo das palavras de fé que lera. Foi o livro Hortensius, de Cícero, que incentivou Santo Agostinho a aproximar-se de Deus e ler a Bíblia, contudo adere ao pensamento maniqueísta.

Já na fase adulta, o Livro IV, nomeado "O Professor" traça sua trajetória de adesão e inicial desilusão ao maniqueísmo - pensamento pela qual, em síntese,entende que só existe o bem e o mal como seu oposto; o envolvimento com uma mulher, através de relacionamento totalmente carnal, pela qual é atraído a concupiscência. Santo Agostinho neste momento sente que sua alma estava doente, pois esta estava ávida por sentimentos sensíveis:

"Era para mim mais doce amar e ser amado, se eu pudesse gozar do corpo da pessoa amada. Assim, eu manchava as fontes da amizade com a sordidez da concupiscência e turbava a pureza delas com a espuma infernal das paixões".

Percebe que o homem não é nada sem Deus, pois Ele é o único e verdadeiro caminho a seguir. Só é feliz quem ama a Deus.

Ato contínuo, o Livro V, denominado "Em Roma e em Milão", reflete as experiências do período compreendido entre os 19 aos 28 anos. Inicia-se esta parte com louvor ao Deus onipotente e oferece suas confissões em sacrifício:

“Zombem de nós os fortes e poderosos: nós, miseráveis e fracos, não cessaremos de nos confessar a ti". 
Continua neste livro o relato da vida em companhia de uma mulher, a quem dizia não estar unido em matrimônio legítimo, mas guiado por uma paixão inquietante. Segue a narrativa com a desilusão ao maniqueísmo e parte para Roma, em busca de sossego para estudar e lecionar retórica:

"Todavia, Senhor, tu bem sabes que eu preferia ter bons discípulos, no verdadeiro sentido da palavra, e, sem artimanhas, eu lhes ensinava artifícios úteis, dos quais pudessem um dia usar, não contra a vida de um inocente, mas, quem sabe, para salvar a vida de um culpado".

Já no Livro VI, apelidado "Entre Amigos", o Santo dedica-se a conta mais sobre a relação com sua mãe, a qual sempre chorava pela alma perdida em pecados de seu filho, mas que a fé lhe consolava:

"Respondeu-me com toda a tranquilidade e com o coração cheio de confiança, que em Cristo ela ainda esperava, antes de morrer, ver-me autêntico católico.”.

Sente grande admiração pelo Bispo Ambrósio, apesar de neste momento ainda não partilhar do celibato, pois encontrava-se tomado pelo apego à matéria. Agostinho começa a ouvir a apalavra da verdade, libertando-se aos poucos do efeito das calúnias feitas ao catolicismo pelos antigos companheiros de seita, desvelando agora o verdadeiro sentido da palavra divina que lhe era apresentada; reconhece, assim, as injustas acusações que fizera à fé católica.

Apesar de reconhecer a fé católica e "preferi-la", ainda entregava-se aos prazeres carnais, considerando-se "escravo do prazer", apesar de reconhecer profundo sofrimento com o fim do relacionamento com sua companheira, aquela que lhe dera um filho.

Em continuidade, o Livro VII, denominado "A Caminho de Deus" versa sobre relatos de sua fase mais madura, na qual começava a reconhecer Deus como único, supremo e verdadeiro, como incorruptível e inviolável, assim como também trata da origem do mal. Não tinha certeza quanto à sua origem, porque não entendia claramente porque a livre determinação da vontade poderia ser a causa do mal.

O penúltimo livro deste parte, conhecido como "A Conversão", discorre sobre o momento da conversão a fé. O livro inicia sua narrativa na dificuldade pessoal em abraçar a fé cristã. O Bispo depara-se em um momento de abandono aos velhos hábitos para um definitivo engajamento na busca e vivência da verdade revelada. Por um instante, Agostinho afirma que hesitou em converter-se, pois suas atenções ainda estavam voltadas para as paixões da carne. Mesmo diante de tamanha hesitação, 
consegue superar todos os obstáculos que o impediam de sua conversão. Frise-se que a conversão de santo agostinho foi lenta e cheia de obstáculos:

“A vontade... de Vos honrar... ainda não se achava apta para superar a outra vontade, fortificada pela concupiscência.

Assim, duas vontades, uma concupiscente... outra espiritual, batalhavam mutuamente em mim. Discordando, dilaceravam-me a alma."

Por fim, o Livro IX, nomeado "O Batismo", inicia contando sobre a primeira consequência da conversão do Santo Africano, a qual foi o pedido de demissão da cátedra em Milão. No ano de 387, inscreve-se entre os catecúmenos e sua preocupação com a vida desregrada e libidinosa do passado desaparece com o batismo aos 33 anos. Nascera, assim, definitivamente, em Deus; no Deus de sua humana compreensão. O Santo volta a África com sua mãe e alguns amigos para melhor servir a Deus. Contudo, sua mãe, Santa Mônica, a cristã exemplar que ele tanto amou, falece.

\section{2 "Segunda Parte: Confissão da Vida como Bispo de Hipona e Louvor a}

\section{Deus."}

Neste momento do livro, o Bispo de Hipona não mais se dedica ao relato de sua vida passada, mas sim como sentia a vida no momento da obra. Ele expõe o desejo de conhecer a Deus e de que suas confissões possam despertar em seus irmãos o mesmo desejo de conversão que a palavra de divina o causou, assim nota-se que Santo Agostinho ama a Deus acima de todas as coisas.

A segunda parte inicia-se com o Livro X, denominado "O Encontro de Deus", pelo qual Santo Agostinho analisa as funções da memória, a qual considera um palácio onde encontram-se os tesouros de inúmeras imagens e lembranças trazidas por percepções e também pelos sentidos. Através da memória ele começa a se conhecer internamente. Ele afirma neste livro que seus males passados estão perdoados, eis que, por suas confissões, Deus esqueceu seus desregramentos:

"[A alma] será feliz quando, liberta de todas as moléstias, se alegrar somente na Verdade, origem de tudo o que é verdadeiro... Onde encontrei a verdade, aí encontrei o meu Deus, a mesma Verdade..."

O Livro XI, nomeado "O Homem e o Tempo, trata basicamente do Gênesis e analisa filosoficamente a essência do tempo. Ao explanar seu entendimento por Gênesis, chega a conclusão de que todas as coisas, céu e terra, foram criadas por Deus e não possuíam existência pretérita, assim também como o tempo. Portanto, não faz sentido 
questionar o que Deus fazia antes da criação, pois o Santo admite não saber a resposta a tal indagação. O passado e o futuro são frutos da imaginação do homem, e o hoje, em Deus, é eternidade.

Já o Livro XII, apelidado "A Criação Agostiana", aborda a questão da criação do mundo e para Santo Agostinho o céu e a Terra foram feitos do nada, mas em contrapartida, tolera, sem descriminação, os que entendem de forma distinta:

“Criastes, portanto, Senhor, o mundo, da matéria informe. Criaste do nada este quase-nada, donde, depois, fizestes as grandes coisas, que nós, os filhos dos homens, admiramos.".

Por fim, o último livro da obra, nomeado "A Paz", revela grande exaltação de Santo Agostinho a sua fé religiosa e seu amor pelo Criador, reconhecendo que Deus sempre falou com ele por diversos modos. Ensina que deve-se viver para servir e honrar a Deus, pois a felicidade somente é encontrada Nele. Acredita na Divida Trindade, de que Deus é Pai, Filho e Espírito Santo.

\section{6. Ética Agostiniana em "A Cidade de Deus".}

\subsection{Contexto histórico}

A "Cidade de Deus", considerada por muitos como a principal obra de Santo Agostinho foi escrita entre os anos 416 a 427 d.C. É considerada uma perspectiva apologética disposta em vinte e dois tomos.

A obra clássica, de leitura obrigatória para estudiosos das ciências humanas, é contemporânea à invasão de Roma pelos Visigodos liderados por Alarico I no famoso saque de Roma em 410 d.C. O referido imperador foi o primeiro dos líderes bárbaros a comandar exitoso ataque ao grande império. Os cidadãos romanos, à época,culpavam o cristianismo pela vitória bárbara. Criam que o Deus cristão era incapaz de defender o império contra seus invasores. No mesmo sentido, parecia-lhes evidente que o povo romano estava sendo severamente castigado por seus deuses pagãos por terem eles abandonado sua fé politeísta. ${ }^{16}$

\footnotetext{
${ }^{16}$ LEÃO, Emanuel Carneiro. "Fé Cristã e História". In:AGOSTINHO. A Cidade de Deus. 7ed. Trad. Oscar Paes Lemes. Rio de Janeiro: Vozes, 2002. p. 17: "Todos, cristãos e não cristãos, acusavam o Cristianismo: o Deus do amor e da caridade não serve para institucionalizar, isto é, organizar e defender uma civilização e uma cultura. 410 é a demonstração prática da fraqueza política do Deus dos cristãos."
} 
Santo Agostinho, à época Bispo de Hipona, tomou para si a missão de defender o cristianismo incutindo na mente do povo romano a ideia de que não seria o Deus Cristão o responsável pela queda do Império. E esse e não outro o objetivo precípuo da referida obra que se tornou um paradigma da filosofia e ética cristãs.

\title{
6.2 Essência da obra
}

Os dez primeiros tomos do livro "A Cidade de Deus" foram redigidos com o intuito de demonstrar que o culto aos deuses pagãos era incapaz de conduzir os fieis à felicidade terrenal e à felicidade eterna. Sempre tomando como sustentáculo as Escrituras Sagradas àquele tempo ainda não unificadas na Bíblia como a temos nos dias de hoje, Santo Agostinho versou exaustivamente acerca da inutilidade de culto aos deuses não Cristãos, estes, incapazes de proporcionar a Vida Eterna. O livro VI da obra Civita Dei contém ecerto que deixa clara a intenção do autor. Veja-se:

\begin{abstract}
Agora, posto que a seguir, como o exige a ordem prescrita, temos de refutar e ensinar os que sustentam que os deuses dos gentios, desvirtuados pela religião cristã, não devem ser adorados pela presente vida, mas por amor à vida que há de seguir à morte, apraz-me dar princípio a minhas palavras pelo verídico oráculo do Salmo sagrado: Bem-aventurado aquele cuja esperança é o senhor e não deteve seus olhos em vaidades e loucuras mentirosas. ${ }^{17}$
\end{abstract}

Os livros restantes versam acerca da "teoria das duas cidades". Segundo o autor, as duas cidades surgem quando da queda dos anjos, narrada no livro de Ezequiel, capítulo 28. O amor incondicional a Deus, que tem como consequência natural o desprezo de "eu" é premissa fundante da Cidade Celestial, enquanto que o amor próprio, egoísta e vaidoso que leva à negação a Deus funda a Cidade Terrena.

No vigésimo livro, Santo Agostinho define o povo como "o conjunto de seres racionais associados pela concorde comunidade de objetos amados" ${ }^{\text {18 }}$. A definição visa levar o leitor a concluir que existem povos que amam os bens terrenais, por isso denominados "povos temporais" da mesma forma que existem aqueles que se aproximam da Cidade Celestial (esta espiritual, não estabelecida no "espaço-temporal) por buscarem a paz e a alegria eternas que provem do Deus Cristão.

\footnotetext{
${ }^{17}$ AgostinhO. A Cidade de Deus. 7ed. Trad. Oscar Paes Lemes. Rio de Janeiro: Vozes, 2002. VI, I, 1. p. 234
} 
A obra do Bispo de Hipona prevê, ainda, a existência de uma Cidade denominada Cidade do Demônio ou CivitasDiaboli que consiste na total negação ao Criador em prol da adoração ao eu. Trata-se da cidade daqueles que obtiveram nesta terra seu galardão posto que a tomaram como fim último de sua existência.

Importa salientar que a "Civitas Dei" e a "CivitasDiaboli" não são materiais ou materializáveis. Não há, portanto, como apontar determinada sociedade como sendo o perfeito exemplo de uma ou de outra. O que ocorre, na verdade é que vivem os homens na Cidade Terrenal que representa uma mistura de ambas as cidades espirituais, mistura essa que se perpetuará até o “juízo final”.

A Cidade Terrenal pode ser vista como um pêndulo em constante movimento que ora se aproxima da Civitas Dei ora se aproxima da CivitasDiaboli sem nunca alcançar qualquer das duas alegorias. O homem é criatura feito à imagem e semelhança de Deus, porém corrompido pelo pecado, razão pela qual não é capaz de se afastar da Cidade de Deus a ponto de materializar a Cidade do Demônio. A corrupção da carne, não o permite, também, por suas próprias forças se fazer cidadão da Civitas Dei.

Santo Agostinho afirma que a Cidade Terrenal que mais se aproxima da Cidade de Deus é Roma e mesmo ela por vezes se deixou aproximar da Cidade do Demônio como quando viveu sob o império de tiramos como Calígula e Nero.

É importante salientar que a dualidade estabelecida por Agostinho consubstanciada na figura das duas cidades representa a dualidade Cristã entre o Corpo e a Alma. A referida dualidade pode ser claramente visualizada no quadro esquemático abaixo:

\begin{tabular}{|l|l|}
\hline CORPO & ALMA \\
\hline Desordem & Ordem \\
\hline Pecado & Virtude \\
\hline Concupiscência & Caridade \\
\hline Orgulho & Amor \\
\hline Paixões Egocêntricas & Ataraxia (imperturbabilidade) \\
\hline$U t i$ & Frui \\
\hline
\end{tabular}




\begin{tabular}{|l|l|}
\hline BiosCarnalis & BiosTheoretikos \\
\hline Caim & Abel \\
\hline
\end{tabular}

Por fim, há que se dizer que a virtude para Santo Agostinho, diferente de seus antecessores, especialmente Aristóteles (que cria ser o referido conceito evidenciado na busca do bem público em detrimento da vida privada), definia a virtude como o supremo amor a Deus e, mais que isso, a entrega incondicional a essa amor que pressupõe o abandono do eu e das paixões carnais.

\section{A ética da deontologia em Santo Agostinho}

O termo Deontologia é fruto da união das palavras gregas "déon, déontos" que quer dizer dever e "lógos" que significa discurso ou tratado. Dentologia é um ramo da filosofia moral que compreender a ciência do dever e da obrigação. Trata-se de uma teoria sobre as escolhas dos indivíduos. Tais escolhas estão sujeitas a julgamento moral que determina como se deve agir a fim de alcançar a plena probidade de conduta.

O termo deontologia foi criado no ano de 1834, pelo filósofo inglês Jeremy Bentham, para conceituar o ramo da ética cujo objeto de estudo consiste nos fundamentos do dever e das normas. Trata-se da chamada "Teoria do Dever"18.

A ética deontológica em Santo Agostinho situa Deus como a fonte, a origem dos mandamentos éticos universais que devem nortear a vida do homem na Cidade Terrenal. A moral, portanto é consubstanciada na figura de Deus e seu caráter, demonstrado nas leis do decálogo, é premissa maior por meio da qual o Criador demonstra ao homem como deve ele, enquanto criatura, agir para alcançar a virtude. Nesse sentido afirma Santo Agostinho que "a moralidade de um ato não depende de suas consequências nem das suas causas, nem da sua natureza, mas somente de que esteja de acordo com a vontade de Deus."

Sendo Deus o Criador, onisciente, onipresente e onipotente, insuscetível a erro, constante e fonte de todo bem, seus ditames enunciados nas Escrituras Sagradas não devem ser alvo de críticas ou questionamentos por parte do homem, mera criatura.

\footnotetext{
${ }^{18}$ Disponível em: http://www.significados.com.br/deontologia. Acesso em: 26 de março de 2013.
} 
Segundo a ética de deontologia de Santo Agostinho, Deus determina e dá causa à moralidade das ações praticadas pelo indivíduo.

É importante salientar que, enquanto teoria teológica, há que se esperar da ética em Santo Agostinho, uma carga de julgamento moral segundo valores pré-concebidos. Nota-se que o fim último da ação na ética religiosa se confunde com a vontade de Deus expressa nos Textos Sagrados ou nos próprios ditames da Igreja.

Há, por oportuno que se mencionar que todas as características acima expostas afeitas ao pensamento ético religioso teológico e, portanto presentes na Ética Agostiniana vêm, contudo, acompanhadas, numa tentativa de conciliação, com o cabedal ético dos gregos. A grande dificuldade enfrentada por Agostinho quando desse empreendimento residiu na conceituação da virtude. Veja-se que em tempos homéricos, "a virtude [...] significava o mais alto ideal cavalheiresco aliado a uma conduta cortesã e ao heroísmo guerreiro ${ }^{19 ",}$ e em Sócrates virtude era "ser o que realmente deseja parecer $^{20}$ ". Nesse sentido, sabe-se que os referidos pensadores valorizavam em demasia especialmente quatro virtudes: a prudência, a justiça, a temperança e a fortaleza. Embora reconheça, Agostinho, o valor de cada uma delas, considera que as mesmas não são transportáveis para dentro da ética e da moral cristãs visto que para a deontologia cristã antes de quaisquer outras virtudes existiam as teológicas que provem da própria figura de Deus, quais sejam a fé, o amor e a esperança. Essas virtudes superavam quaisquer outras.

Por vezes foi, Santo Agostinho, alvo de críticas por aqueles que consideraram filosofia (e ética) e religião de difícil conciliação. Nesse sentido veja-se argumento de Tertuliano no seu escrito "A sabedoria deste século:

\footnotetext{
"a filosofia é a matéria básica da sabedoria mundana, intérprete temerária da natureza e da ordem de Deus. De fato, as próprias heresias são equipadas pela filosofia. Ela é a fonte dos 'eons', das 'formas' infinitas e da 'trindade do homem' no sistema Valentiano. Ela gerou o 'bom deus' de Marcion, o 'bom deus' sossegado que vem dos estóicos. Quando Marcion afirma que alma perece, obedece a Epicuro; [...] quando confunde a matéria com Deus, repete a lição de Zenon; quando alude a um deus de fogo, torna-se aluno de Heráclito. Hereges e filósofos manipulam o mesmo material... ${ }^{21,}$.
}

\footnotetext{
${ }^{19}$ SOUZA, José Cavalcante. Os Pré-Socráticos - Vida e Obra. São Paulo: Nova Cultural, 1999 p.9.

${ }^{20}$ PESSANHA, José Américo Motta. Sócrates, Vida e Obra. São Paulo: Nova Cultural, 1999, p. 115.

${ }^{21}$ BETTENSON, Henry. Documentos da Igreja Cristã. São Paulo: ASTE, 2001, p.33.
} 
É imperioso concluir que não foi, para Santo Agostinho, uma tarefa fácil harmonizar a filosofia e a ética gregas que fortemente o influenciaram durante os primeiros anos de estudo com os valores éticos e morais cristãos assimilados após sua conversão. Árdua foi, também, a tarefa de teorizar acerca de uma teologia ainda nascitura e desenvolver um discurso dirigido a uma sociedade complexa, desenvolvida, que muito herdara da sabedoria e do pensamento grego e, principalmente, milenarmente politeísta. O mérito de Santo Agostinho consiste em ter se tornado um verdadeiro estadista eclesiástico que se empenhou em teologizar para a Igreja Cristã sob uma perspectiva não meramente existencial ou metafísica.

É certo que Santo Agostinho inaugurou o pensamento segundo o qual o amor a Deus consiste na clara divisa entre o bem e o mal. O Bispo de Hipona foi capaz de idealizar a conduta de homem cidadão, súdito cristão que alcançaria a virtude subordinando todo e qualquer princípio aos teologais estabelecidos por Deus e dispostos no Evangelho Sagrado.

\section{8. $\underline{\text { Referências }}$}

AgOSTINHO. A Cidade de Deus. 7 ed. Trad. Oscar Paes Lemes. Rio de Janeiro: Vozes, 2002.

BELLEI, Ricardo J.; BUZINARO, Délcio Marques. O livre-arbítrio e o mal em Santo Agostinho. Disponível em: http://www.revistamirabilia.com/nova/images/numeros/2010_11/04.pdf. Acesso em: 25de março de 2013.

BETTENSON, Henry. Documentos da Igreja Cristã. São Paulo: ASTE, 2001.

COSTA, Marco Roberto Nunes. "O amor: princípio da moral interior em Santo Agostinho". In: Revista Perspectiva Filosófica. Disponível em: http://www.ufpe.br/ppgfilosofia/images/pdf/pf09_artigo80001.pdf. Acesso em: 24 de março de 2013. 


\section{Quaestio Iuris}

COUTINHO, Gracielle Nascimento. "O Livre-arbítrio e o Problema do Mal em Santo Agostinho". In: Revista Argumentos, ano 2, $\mathrm{n}^{\circ} 3$ - 2010. Disponível em: http://www.filosofia.ufc.br/argumentos/pdfs/edicao_3/16.pdf. Acesso em: 24 de março de 2013.

GONÇALVES, Adriano José. Introdução às Confissões de Santo Agostinho. Disponível em: http://www.catequisar.com.br/texto/colunas/adriano/10.htm. Acesso em: 26 de março de 2013.

LAW, Stephen. Guia ilustrado Zahar: filosofia. Tradução: Maria Luiza X. de A.

Borges; revisão técnica: Danilo Marcondes. Rio de Janeiro: Jorge Zahar Ed., 2008.

NADER, Paulo. Filosofia do direito. Rio de Janeiro: Forense, 2009.

PESSANHA, José Américo Motta. Sócrates, Vida e Obra. São Paulo: Nova Cultural, 1999.

SOUZA, José Cavalcante. Os Pré-Socráticos - Vida e Obra. São Paulo: Nova Cultural, 1999. 